\title{
Lethal Palm Diseases Common in the United States
}

\author{
A. James Downer ${ }^{1,5}$, Janice Y. Uchida ${ }^{2}$, Donald R. Hodel ${ }^{3}$, and \\ Monica L. Elliott ${ }^{4}$
}

AdDITIONAL INDEX WORDS. diamond scale, fusarium wilt, ganoderma butt rot, lethal yellowing, Nalanthamala, Gliocladium, Phytophthora, polymerase chain reaction, Thielaviopsis

Summary. Palms (Arecaceae) are affected by a variety of pathogens, most of which are fungi. We detail pathogens, host ranges, disease description, diagnosis and epidemiology as well as management for the significant, usually fatal, diseases affecting palms grown in the continental United States and Hawaii. These include fusarium wilt (Fusarium oxysporum f.sp. canariensis) of canary island date palm (Phoenix canariensis), diamond scale (Phaeochoropsis neowashingtoniae), ganoderma butt rot (Ganoderma zonatum), lethal yellowing (Candidatus Phytoplasma palmae subgroup 16SrIV-A), and diseases caused by Nalanthamala (Gliocladium), Phytophthora, and Thielaviopsis. We have omitted the leaf spot and minor blight diseases that often affect palms but pose no long-term consequence to their health and survival. Visual symptoms of lethal palm diseases are often similar, necessitating the isolation or detection of the pathogen with cultural, microscopic, or molecular methods. Management of palm diseases is varied, often requiring in-depth knowledge of the biology of the pathogen and its' infection process. Quarantine, eradication, sanitation, and proper species selection and culture are necessary practices to limit the spread of new and existing diseases of palms in landscapes and nurseries.

\section{Canary island date palm wilt}

Pathogen and host Range. The pathogen Fusarium oxysporum f.sp. canariensis causing date palm wilt has been reported primarily on canary island date palm (Simone, 2004a), but wilt symptoms have also been observed on senegal date palm (Phoenix reclinata), wild date palm (Phoenix sylvestris), and on seedlings of date palm of commerce (Phoenix dactylifera) (Feather et al., 1989; Simone, 2004a). Despite widespread planting of date palms in southern California where canary island date palm wilt is widespread, there have been no reports of mature, transplanted date palm of commerce with this disease in California, suggesting that mature date palms may not be susceptible to this pathogen. The pygmy date palm

\footnotetext{
${ }^{1}$ University of California Cooperative Extension, 669 County Square Drive, Suite 100, Ventura, CA 93003

${ }^{2}$ Department of Plant and Environmental Protection Sciences, University of Hawaii, Honolulu, HI 96822

${ }^{3}$ Fort Lauderdale Research and Education Center, University of Florida Institute of Food and Agricultural Sciences, 3205 College Avenue, Davie, FL 33314

${ }^{4}$ University of California Cooperative Extension, 4800 East Cesar Chavez Avenue, Los Angeles, CA 90022

${ }^{5}$ Corresponding author. E-mail: ajdowner@ucdavis. edu.
}

(Phoenix roebelinii) is not a known host for this pathogen (Simone and Cashion, 2002). Unpublished reports of the disease occurring in the california fan palm (Washingtonia filifera) in California require further study and confirmation.

DESCRIPTION, DiAgNOSIS, EPIDEMIOLOGY. The disease affects the vascular system of the palm by occlusion of xylem vessels with macroconidia and hyphae thereby blocking the movement of water into affected leaves. The disease arose worldwide in the 1970s in Japan, Italy, the United States (California), and France (Arai and Yamamoto, 1977; Corte, 1973; Feather et al., 1979; Mercier and Louvet, 1973). The disease was not observed in Florida until the 1990s (Simone and Cashion, 2002). The first symptom is fronds dying in the lowest portion of the canopy (older leaves). The pathogen spreads upward in the canopy, eventually killing all the leaves, including those in the bud that have not emerged. Palms die of the disease in all locations but the demise of infected palms along the coast of California appears to take more time. We observed that palms infected with the disease in the city of Dana Point, $\mathrm{CA}$, remain alive for a number of years while palms in a more inland location at Irvine, CA, died in less than 1 year after the onset of symptoms. Simone (2004a) similarly notes that mature palms can die in as little as a few months up to 2 years. The pathogen can survive in California soils for up to 25 years (Downer, 2006).

Diagnosis often begins with the observation of foliar wilt symptoms. In many cases, there may be unilateral death of pinnae on one side of a leaf, giving a one-sided wilt symptom. Accompanying death of pinnae is an external browning on the rachis and internal vascular discoloration that can be observed on longitudinal or transverse cuts of petioles or the rachis of a symptomatic leaf. Vascular discoloration is light brown to red brown or bright pink (Feather et al., 1979; Simone 2004a). The pink discoloration is vibrant and striking but has also been observed without the pathogen and in trees with mixed infections of canary island date palm wilt and pink rot disease [Nalanthamnala vermoeseni (see below)] and or in palms with only pink rot (H. Ohr, personal communication). Observation of bright pink staining in the xylem should not be used as the only diagnostic indication of the disease. Occasionally, wilt symptoms may start in midcanopy, making a one-sided decline appear in the palm (Simone and Cashion, 2002). It should be noted that other fungi that cause rachis blight also may cause one-sided frond death symptoms (Downer, 2003a; Elliott, 2006a). These fronds will be in the lower canopy and although they may succumb with one-sided death symptoms, such decline will not permeate the tree. Although Feather et al.

\begin{tabular}{llll}
\hline $\begin{array}{l}\text { Units } \\
\begin{array}{l}\text { To convert U.S. to SI, } \\
\text { multiply by }\end{array}\end{array}$ & U.S. unit & SI unit & $\begin{array}{l}\text { To convert SI to U.S., } \\
\text { multiply by }\end{array}$ \\
\hline 0.3048 & $\mathrm{ft}$ & $\mathrm{m}$ & 3.2808 \\
2.54 & inch $(\mathrm{es})$ & $\mathrm{cm}$ & 0.3937 \\
25.4 & inch $(\mathrm{es})$ & $\mathrm{mm}$ & 0.0394 \\
$\left({ }^{\circ} \mathrm{F}-32\right) \div 1.8$ & ${ }^{\circ} \mathrm{F}$ & ${ }^{\circ} \mathrm{C}$ & $\left(1.8 \times{ }^{\circ} \mathrm{C}\right)+32$
\end{tabular}


(1979) described this wilt disease as a complex between pink rot and canary island date palm wilt, the wilt symptoms only occur in the presence of the canary island date palm wilt pathogen and not when palms are only infected with pink rot. The pathogen is best isolated from the petioles or the base of the rachis of symptomatic fronds. Summerell et al. (2006) maintain that the pathogen can be recovered from asymptomatic (but infected) stems of trees with an increment borer.

Disease confirmation should not be made on a visual inspection of palms for symptoms but rather on a combination of symptoms, pathogen isolation, and pathogen identification. A method using the polymerase chain reaction (PCR) has been developed for canary island date palm wilt identification (Plyler et al., 1999), and this method has been successfully used in California and Florida to identify this pathogen. Although highly specific, false-negative results may occur when other Fusarium fungi that are palmpathogenic do not hybridize with the specific primers developed (A.J. Downer, unpublished data; Elliott, 2006a; Gunn and Summerell, 1999). PCR negative isolates of the fungus have been found in California that can cause the disease in canary island date palm (A.J. Downer, unpublished data).

The fungus spreads from palm to palm by infection of leaves with contaminated pruning equipment (Feather, 1982). Movement of infested soil and infected seed also spreads the pathogen (Simone, 2004a).

Management. Control measures center on detection, prevention of spread, and eradication of diseased palms. To minimize spread with contaminated pruning equipment, the most conservative method is to use a new saw on every palm pruned. If saws are reused, Elliott (2006a) suggests using various compounds such as sodium hypochlorite or ethanol to soak the tools for their disinfection. A minimum soak time of $5 \mathrm{~min}$ is recommended. Downer (2009) has shown that a butane torch can sterilize a pruning saw in as little as $10 \mathrm{~s}$. Other practices to limit the spread of disease is to not plant or transplant an infected tree into a landscape and to avoid replanting canary island date palm in the same planting hole where the disease has already killed a palm. Once the disease is established in a new site, it is recommended that infected trees be removed whole and cut up at another location. This is expensive and involves crane operation, and transport and disposal fees, but is the only way to prevent the spread of inoculum that is created with chain saws used to cut the trunk in sections.

\section{Diamond scale}

Pathogen AND host RANGe. Although diamond scale sounds like an insect pest, the disease is caused by a fungus. The diamond-shaped, scalelike fruiting bodies are stroma that contain the reproductive structures (perithecia) and ascospores that serve as primary inoculum for new infections. The stroma form on upper and lower leaf surfaces simultaneously (Elliot, 2004a).

The host range of the pathogen is limited to fan palms in the genus Washingtonia, with california fan palm being the most affected. The pathogen has been observed on mexican fan palm (Washingtonia robusta) in southern California on cultivated palms and in Sonora, Mexico on wild palms (Hodel, 2009). Hybrids of these two fan palms are common in California, and they appear to be intermediate in their susceptibility to the pathogen, showing modest disease development.

DESCRIPTION, DiAgnosis, EPIDEMIOLOGY. The pathogen infects the leaf blade, rachis, and petiole and occurs first on the oldest leaves, moving upward into the canopy to about the fourth or fifth newest leaf. New infections appear as a circular, watersoaked lesion of 1 to $3 \mathrm{~mm}$ in diameter. The tissue soon yellows and the first stroma is immediately produced. The stroma grows as long as the leaf is green and can reach up to $1 \mathrm{~cm}$ length with the points of its diamond shape following the long axis of the leaf. New infections continue to form on all parts of the leaf surface until the leaf yellows and dies. Older palms growing in less favorable conditions, such as california fan palm in coastal climates, will sustain extensive loss of leaves from this pathogen until only a few leaves remain in the canopy. The fungus is common in California but has also been reported in Arizona and Nevada.

Management. While practitioners in southern California routinely use thiophanate-methyl to increase canopy vigor and sustain old trees with diamond scale infections, the efficacy of these treatments has not been studied. Downer and Hodel (2007) found that the pathogen can infect new leaves and produce fruiting bodies in less than 3 months, and the pathogen is active year-round at Long Beach, CA. Complete leaf removal did not stop new infections from occurring, suggesting that pruning has little effect on this disease if an inoculum source is nearby.

\section{Ganoderma butt rot (basal stem rot)}

Pathogen and host RANGe. Ganoderma butt rot or basal stem rot is caused by a fungus. The most common and lethal disease of palms throughout Florida, it has been observed on nearly all common palms as well as rarer species in this state (Elliott and Broschat, 2001); the disease has also been reported on palms in other states in the Gulf of Mexico and Atlantic coastal regions of the continental United States (Elliott, 2004b). A similar, if not the same, disease has been rarely observed on senegal date palm and queen palm in California.

DESCRIPTION, DiAgNosis, EPIDEMIOLOGY. Ganoderma butt rot results in mild to severe wilt symptoms, reduced growth, and general chlorosis and necrosis of foliage, beginning with the oldest leaves. Primarily a disease of palms with well-developed trunks, the soil-borne fungus causes internal rot in the basal $2 \mathrm{~m}$ of trunk. Infected palms typically have an inordinate number of dead leaves in the lower part of the crown, and the disease is always lethal. Because foliar symptoms are similar to those of other diseases and disorders, and diagnostic basidiomata (conks or fruiting bodies) are not always produced, the disease can often only be confirmed when the palm is removed and the lower trunk sections are examined for characteristic discoloration of internal trunk tissue. Cross sections of infected trunks show a central area that is markedly different in color and is often distinguished from surrounding healthy tissue by a distinct boundary or dark line (Elliott, 2004b).

By the time foliar symptoms are apparent, usually more than half the 
tissue in the lowest portion of the trunk has been destroyed (Elliott, $2004 b$ ). Infections start on belowground trunk tissue, expanding in diameter, and progressing internally upward in the center of the trunk, usually to no more than $2 \mathrm{~m}$ high. After the palm has died, infections frequently spread into the roots. Basidiomata may form when the fungus reaches the outside of the trunk, and disease diagnosis is easy if they are present. Initially white, flat, and irregular to circular in shape, they expand and mature to a distinct, hard, shelflike structure that is a lacquered reddish brown with white underside. Basidiomata are up to $20 \mathrm{~cm}$ wide and $5 \mathrm{~cm}$ thick and attached in a sessile manner to the outside of the trunk (Elliott, 2004b). Production of fruiting bodies is variable: they may never form or they can even appear before the onset of foliar symptoms. Fruiting bodies can form year-round in the nearly constantly warm and humid southern Florida climate, but appear only in the warmer months in more temperate areas. Single-trunked palms usually die within 1 year of the appearance of basidiomata, while death may take longer in multitrunked specimens (Elliott, 2004b).

Spores and the movement of infected palm parts, including roots, stumps, and boles, likely spread the disease. The fungus readily colonizes and rots dead palm stumps or trunks, forming basidiomata that release spores into the landscape (Elliott, 2004b). There are no known factors, including environmental conditions, soil types, and landscape management practices that predispose palms to infection (Elliott, 2004b).

Management. There is no control once a palm is infected. Fungicides are ineffective. Prevention through exclusion and sanitation is the only option. Because the disease is largely confined to the basal portion of palm trunks, it is not spread on tools during leaf pruning (Elliott, 2004b). Multitrunked palms should not be thinned because the remaining stump can be colonized (Elliott, 2004b; Hodel, 1999). We recommend frequent monitoring; if fruiting bodies are found, promptly remove the infected palm to a landfill or incinerate. Do not recycle trunks of diseased palms as green waste or chip and use basal portions of palm stems as mulch. If possible, remove infected palms as a single, intact unit (trunk and attached root ball together) to prevent the spread of inoculum (Elliott, 2004b). If this is not possible, grind the stump to allow for faster decomposition of this host material to minimize colonization and resulting basidiomata development. Do not replant a palm in the same location where one died from ganoderma butt rot because the fungus likely survives in soil.

\section{Pink rot}

Pathogen and host range. Gliocladium blight, pink bud rot, and pink rot are common names for a series of disorders caused by the fungus Nalanthamala vermoeseni, which will all be termed pink rot hereafter for simplicity. The pathogen was first reported in 1938 by Bliss as Penicillium vermoeseni and later as Gliocladium vermoeseni. Schroers et al. (2005) proposed the fungus be reclassified in the genus Nalanthamala with no known teleomorph. The fungus typically produces long chains of salmon pink conidia. It sporulates abundantly in culture and on many palm surfaces. It is distributed worldwide. The fungus grows well at $24{ }^{\circ} \mathrm{C}$ but is inactive above $33^{\circ} \mathrm{C}$ (Atilano et al., 1980). Thus, its presence in cool coastal communities is favored over hot inland climates. In date palms, the disease often occurs simultaneously with canary island date palm wilt (Feather et al., 1979). The fungus also commonly causes disease in the genera Archontophoenix, Chamaedorea (bamboo palms), Dypsis, Trachycarpus, Syagrus, and Washingtonia.

DESCRIPTION，DIAgNOSIS, EPIDEMIOLOGY. Pink rot causes leaf spots, petiole and rachis blights and decay, sheath rot, and bud rots and trunk rots on susceptible palms, but disease is most often expressed as two distinct types: a bud rot and a trunk rot. In many species of palms, damage to the apical meristem (bud) may kill the palm or cause newly formed leaves to stunt, twist, or not fully expand even after other leaves have emerged from the bud. The fungus is a very competent saprophyte and will grow on senescent leaves, dead leaf bases, bracts of the subtending inflorescences, or the clasping leaf bases of palms with a crownshaft. In king palm ( $A r c h-$ ontophoenix cunninghamiana) and bamboo palms, a trunk rot is common. When a trunk rot is present, a necrotic lesion will appear on the green trunk tissue surrounded by a water-soaked margin of the advancing canker. Salmon pink-colored spores follow in the oldest portion of the canker. The fungus is a potent rotter and will grow through the main stem until it fails. Often palms with basal cankers do not have foliar symptoms. This fungus is frequently associated with stem rots in queen palm (Syagrus romanzoffianum), but is rarely observed sporulating on stems of this species in California (Downer, 2003b). A review of the literature indicates that Koch's postulates were never conducted on queen palm for the trunk rot disease. Recent observations in coastal California of queen palms with trunk decays revealed various wood decay fungi such as Sistotrema spp. and Antrodia spp., but pink rot sporulation was not observed in the cankers or at their margins as is commonly seen on king palm. The most diagnostic sign of the presence of pink rot is its abundant salmon or pink spore masses. However, the fungus also causes internal discolorations in the rachis of affected canary island date palm that stain the xylem darkly. Sometimes pink rot will cause one-sided death of fronds identical to the symptoms caused by canary island date palm wilt. Feather et al. (1979) observed a bright pink staining in cross sections of canary island date palm petioles, but whether this was the result of the pink rot pathogen or the associated canary island date palm wilt pathogen was not determined.

Pink rot is spread by wind-blown spores and splashing water (Uchida, 2004a). The fungus is especially prolific in areas of higher humidity and cool temperatures, such as along the coast of southern and central California. The fungus is invasive and able to colonize weakened hosts to produce its copious spore masses that are then further disseminated to other weak, wounded, or susceptible palms.

Management. Avoidance of wounds and growing healthy, unstressed palms are critical in limiting the disease. Wounding is an essential requirement for infections in some bamboo palms (Atilano et al., 1980; Hodel, 1985) and king palm (Downer, 2003b). King palm and kentia palm (Howea forsteriana) are especially susceptible to the fungus when old leaves 
are removed and a tear occurs at the base of the crownshaft. Infections in the buds of windmill palm (Trachycarpus fortunei), california fan palm, mexican fan palm, and date palm are often seen after freezing weather events in southern California or whenever palms are stressed from other abiotic factors such as drought, transplanting, overpruning, or other biotic disease interactions (canary island date palm wilt, diamond scale, or phytophthora bud and collar rot). Thus, a critical part of disease control involves the healthy maintenance of cultivated specimens and choosing not to grow poorly adapted palms along the coast or in cool humid climates. Sanitation by pruning (not tearing) dead leaves and other dead tissues limits fungal infection. Increasing air movement and scheduling irrigations to avoid night leaf wetness can help limit disease. Restrict pruning to dry periods when temperatures exceed $30^{\circ} \mathrm{C}$ (if possible) and refrain from removing leaves with green tissues, as the wounds are susceptible to infection (Uchida, 2004a).

Control of pink rot disease was effectively achieved with benomyl in bamboo palms (Atilano et al., 1980: Humphrey and Keim, 1984). Thiophanate-methyl, another benzimidazole fungicide, is widely used today to slow the progress of the fungus when it occurs in palms. A fungicide screen against pink rot suggests that some of the more recent fungicide chemistries may provide excellent control of pink rot diseases (A.J. Downer, unpublished data).

\section{Lethal yellowing}

Pathogen and host range. A phytoplasma (unculturable, cell wallless bacterium) likely transmitted by a plant hopper insect, Myndus crudus, causes lethal yellowing (Harrison et al., 2002). About 36 species of common landscape palms are susceptible to lethal yellowing in Florida (for a list, see Harrison and Jones, 2004). In addition, coconut palm (Cocos nucifera), christmas palm (Adonidia merrillii), date palm, and pacific fan palm (Pritchardia spp.) have sustained extensive losses in the landscape.

DESCRIPTION, DiAgNosis, EPIDEMIOLOGY. First observed on coconut palm in Jamaica in the 1800s, lethal yellowing spread to southeastern Florida where, by the 1970s, it had killed nearly all the particularly susceptible, tall-type coconut palms (Harrison and Jones, 2004). As the name implies, lethal yellowing kills palms-often quickly-and is incurable.

A sequential and progressive development of symptoms characterizes lethal yellowing, which helps to distinguish it from other diseases and disorders that can cause similar but isolated symptoms (Harrison and Jones, 2004). The first symptoms are premature fruit drop and inflorescence necrosis. For tall-type coconut palms and many palm species, leaves turn yellow progressively from the lower part of the crown (older leaves) to the upper part of the crown (younger leaves). Affected yellow leaves typically remain turgid before browning, drying, and hanging down. The newly emerging spear leaf finally collapses and the entire crown withers and topples off, leaving a bare trunk. The apical meristem dies when onehalf to two-thirds of the leaves have yellowed (Harrison and Jones, 2004). While premature fruit drop and inflorescence necrosis is common to all palms with lethal yellowing, typical leaf yellowing does not occur with all species or all coconut cultivars. In some species and in the dwarf-type coconuts, progressively affected leaves turn reddish to grayish brown rather than yellow (Harrison and Jones, 2004), and in date palms, the spear leaf dies shortly after the leaves begin to discolor.

Diagnosis is largely dependent on careful analysis of the distinctive sequential symptoms. Because phytoplasmas cannot be cultured and are too small to see with a compound microscope, pathogen detection is based on molecular methods, using PCR that employs tissue shavings from a small hole drilled in the trunk of symptomatic palms (Harrison and Jones, 2004).

Management. The use of diseaseresistant species and quarantines to discourage movement of living palms from lethal yellowing areas are the best long-term solutions for disease management. Liquid trunk injections of the antibiotic oxytetracycline hydrochloride every 4 months at early onset of symptoms stops or slows disease progression, but may not kill the pathogen. Antibiotic treatment may not be effective, though, once palms have more than $25 \%$ of leaves discolored (Harrison and Jones, 2004). Preventive antibiotic used in conjunction with a judicious integrated pest management program can offer significant protection to palms in lethal yellowing areas. Vector suppression with insecticides is not feasible (Harrison and Jones, 2004).

Because of the devastation caused by lethal yellowing in southeastern Florida in the 1970s, palm species other than coconuts were planted to create more diverse palm plantings in landscapes. Initial field trials in Jamaica suggested that malayan dwarf and maypan coconut cultivars were resistant to lethal yellowing. However, further evaluation of these cultivars in Florida demonstrated that while they were less susceptible than the once common jamaica tall coconut, they were still highly susceptible (Broschat et al., 2002). Coconut culture in Florida remains difficult at this time.

\section{Phytophthora bud rot and stem and collar rot}

Pathogen and Host RANGe. Phytophthora palmivora, perhaps the most commonly reported Phytophthora, is responsible for bud rot in Florida on a wide range of species. In Hawaii, Phytophthora katsurae is responsible for bud rot on coconut palm (Uchida, 2004b). In California, Phytophthora drechsleri or related species may cause stem and collar rot on mexican fan palm (Keim et al., 1979).

DESCRIPTION, DiAgnosis, EPIDEMiology. Several Phytophthora spp. cause a variety of serious diseases on many species of palms throughout the world, including seedling blights and damping off, root rots, leaf spots, stem and collar rots, and bud rots. Bud (heart) rot is lethal because most palms have unbranched trunks and there is only one apical meristem per trunk. Phytophthora bud rot is particularly serious in Hawaii on coconut palm, where it has killed hundreds of trees in wet areas such as Kauai, Hilo, and Waimanalo (Uchida et al., 1992a, 1992 b). An early symptom in Hawaii is the premature loss of fruits with circular brown lesions forming distinctive and characteristic, green, island-like, uninfected circles. Another important symptom is the death of the youngest emerging leaf, at which time the bud is rotted and the tree will die. The progressive loss of 
young then older leaves produces a palm with a skirt of older leaves and no young leaves (Uchida, 2004b).

Phytophthora bud rot has also been reported from young, fieldgrown mexican fan palm and california fan palm in Florida (Uchida, 2004b). Newly emerging spear leaves fade to pale green and palms show a general decline in growth. Spear leaves eventually turn brown and petiole bases and leaf bases have tan, necrotic lesions with brown margins. Infected leaves are readily pulled off as the apical meristem rots and the dying palm collapses (Uchida, 2004b).

Phytophthora stem and collar rot has also been reported on containerized mexican fan palm (Keim et al., 1979) and observed on field-grown mexican fan palm in California. Infected palms lost vigor and displayed light green leaves. As the disease progresses, leaves turn yellow then brown and dry. Basal rots with mottled, water-soaked edges encircle $40 \%$ to $60 \%$ of the stem and often progress upward for at least $1 \mathrm{~m}$ (Uchida, 2004b).

Like most diseases caused by Phytophthora spp., moist or wet conditions, poor drainage, and wet foliage drastically enhance development and spread of the diseases. Disease progression is slower in dry areas. In general, palms grown in shade and young palms are more susceptible. Sporangia or spores are formed on diseased tissue and are splashed to neighboring palms. A white or creamcolored growth on the surface of diseased fruits and stems is indicative of these spores. At times, white cottony growths on the surface of badly infected palms are a sign of pathogen presence.

In the presence of free water, zoospores (swimming spores) are released from sporangia and can increase the range of spread of the pathogen. Zoospores can migrate to plant wounds or aggregate to penetrate the host. They can be common in standing water on benches, in ditches, streams, and water sources used for nursery and landscape irrigation. Many nurseries that recycle water must pay strict attention to the elimination or reduction of these pathogens in the water supply.

Each zoospore forms a germ tube that penetrates the host through stomatal pores or intercellular penetration.
Once inside the host, the pathogen releases enzymes that degrade the cells, releasing nutrients, and providing food for the pathogen to grow and move deeper into the host. Sporangia can also form germ tubes that penetrate the host epidermis directly (Uchida, 2004b).

Phytophthora species survive by producing thick-walled oospores (P. katsurae) or thick- walled chlamydospores ( $P$. palmivora). These survival spores are able to withstand environmental stresses such as lack of nutrients (host), desiccation, and microbial attack. The palm bud rot pathogen survives for many months and up to 1 year in soil. Chlamydospores germinate when stimulated by the host exudates (Uchida, 2004b).

The disease is also spread by movement of infected palms and soil, and possibly by leaf pruning when saws and other pruning tools become contaminated with infected tissue or spores and then transferred to cut petioles of healthy palms. Insects, birds, slugs, snails, and people can move spores.

Field diagnosis is made by the distinctive symptomatology and confirmed through isolation of the pathogen and, if necessary, serological or molecular identification methods. Isolating the pathogen from the bud rot can be extremely difficult, though, because infected tissue is quickly invaded by yeast, bacteria, and other fungi that prevent the establishment of the pathogen in agar. Many areas within the heart are void of the pathogen, and microscopic location of diseased areas with oospores is time consuming. Once these areas are found, the pathogen can be isolated with a selective medium (Uchida, 2004b).

MANAgEMENT. Prevention through exclusion and sanitation offers the best control of these diseases. Using clean propagative techniques, including starting with clean seeds and plants, planting in clean soil and clean pots, and following rules of sanitation and proper culture is essential to avoid these diseases. Clean containers by soaking in $20 \%$ household bleach for $10 \mathrm{~min}$. Wherever possible, keep plants on clean benches at least $60 \mathrm{~cm}$ above the ground. Remove and dispose infected and dead plants and plant parts.

Moisture management is critical. Provide proper drainage and do not overirrigate. Adjust emitters to avoid applying water on trunks and foliage. Increase air movement around plants to encourage drying and reduce free water on the leaves and bud. Increase space between plants, prune dead leaves and adjacent vegetation, and irrigate early in the morning to allow for dry foliage by night. Control slugs, snails, birds, rodents, and other animals that can spread the disease. Ensure that palms entering the nursery or landscape site are disease free.

Fungicides, such as fosetyl-aluminum, mefenoxam, and propamocarb, in conjunction with integrated pest management strategies, may prevent diseases and eliminate small infestations. However, they are mostly ineffective on massive or advanced infections that frequently characterize bud rots and stem and collar rots (Uchida, 2004b).

\section{Thielaviopsis trunk rot}

Pathogen and host RANGe. The fungus Ceratocystis paradoxa (anamorph Thielaviopsis paradoxa) causes thielaviopsis trunk rot, attacking as least 16 palm species in Florida (Garofalo and McMillan, 2004). This fungus is soil-borne and forms resting spores (chlamydospores) for long-term survival in soils. It is common and adapts to all ecotypes.

DESCRIPTION，DIAGNOSIS, EPIDEMIOLOGY. While thielaviopsis trunk rot can affect all parts of the palm, here we primarily discuss the trunk rot disease. Infections can begin at or near the ground or in the roots and move up the trunk, but they more frequently initiate in the upper part of the trunk (Elliot, 2006b), perhaps because tissues are less lignified there or wounding from leaf removal and trunk skinning facilitates entry of the pathogen. A soft, somewhat yellowish decay that dries and darkens to brown or nearly black is characteristic of these trunk rots. Like ganoderma butt rot, there is typically a sharp transition between infected and healthy internal tissues. Exterior cavities and reddish brown bleeding may occur, but frequently the pseudobark appears undamaged and intact. Lodging and sudden breaking and falling of the entire crown, leaving a bare, crownless trunk, can occur without any apparent foliar symptoms (Simone, 2004b).

In southern California, thielaviopsis trunk rot or a similar disease 
has significantly affected canary island date palm and, to a lesser extent, the date palm of commerce in the landscape, where it causes an interior wet or dry trunk decay. Coined "sudden crown drop" (Hodel, 2009), the decay cannot be detected visually from the outside because the pseudobark appears normal and intact, and sufficient healthy tissue remains inside the trunk to maintain a normalappearing crown of leaves. However, this amount of healthy tissue is insufficient to maintain the structural stability of the tree. Eventually, and without warning, the immense weight of the crown of leaves and ball (the "pineapple") or excessive wind load causes the trunk to snap and brings down the destructive and potentially deadly crown and upper part of the trunk. While Thielaviopsis spp. has been isolated from fallen heads of canary island date palm, it has not been confirmed that this pathogen is the primary cause of the disease.

Several cultural factors favor trunk rot disease severity and development. Wounding of the trunk and petioles during various horticultural tasks, such as leaf removal and transplanting may be the most significant. We surmise that in California, the pervasive and extensive use of chain saws to prune leaves, to shape and sculpt pineapples, and to skin trunks of canary island date palms facilitates entry of the disease by creating gaping wounds (Hodel, 2009). Drought stress may also render palms more vulnerable to infection (Simone, 2004b).

Examination and culture of darkened, infected trunk tissue can reveal the pathogen. Characteristic conidia and chlamydospores can often be detected on decayed tissue with simple microscopic examination. However, recovery is more likely on suitably cultured tissue (Simone, 2004b).

Management. Prevention by avoiding wounds offers the best disease management. The use of chain saws and tree spikes is discouraged, not only because of the wounds they make but also because they can spread inoculum. Use hand or pole saws and thoroughly disinfect blades before use on each tree. Prune, remove, and appropriately discard infected material and palms. Do not recycle or chip infected material for use as mulch because it can contain the pathogen (Simone, 2004b). The use of a heavy mallet to pound and sound systematically for hidden decay in the upper part of the trunk can be useful in disease detection, and should probably be performed routinely on frequently pruned palms, especially if there is current or a past history of chainsaw use (Hodel, 2009). While preventive use of thiophanate methyl and related chemistry fungicides may be effective on seedlings and young palms in a nursery setting or recent trunk infections (Garofalo and McMillan, 2004), it is ineffective on large palms with extensive trunk rot (Simone, 2004b).

\section{Conclusions}

Palms are affected by a variety of pathogens, but the majority of them are fungi. While disease identification based on field symptoms may be adequate for some situations, the similarity of field symptoms necessitates the isolation or detection of the pathogen with cultural, microscopic or molecular methods. Management of palm diseases is varied, often requiring an in-depth knowledge of the biology of the pathogen and its infection process. In most cases, fungicides appear to be of limited use, but many of the newer fungicidal chemistries have not yet been screened for efficacy against the various pathogens. In the case of lethal yellowing, an antibiotic is effective but very costly. Quarantine, eradication, sanitation, and proper species selection and culture are necessary practices to limit the spread of new and existing diseases of palms in landscapes and nurseries.

\section{Literature cited}

Arai, K. and A. Yamamoto. 1977. New Fusarium disease of canary island date palm in Japan. Bul. Faculty Agr. Kagoshima Univ. 27:31-37.

Atilano, R.A., W.R. Llewellyn, and H.M. Donselman. 1980. Control of Gliocladium in Chamaedorea palms. Proc. Florida State Hort. Soc. 98:194-195.

Broschat, T.K., N.A. Harrison, and H. Donselman. 2002. Losses to lethal yellowing cast doubt on coconut cultivar resistance. Palms 46:185-189.

Corte, A. 1973. La tracheomicosi da Fusarium oxysporum $\mathrm{f}$. sp. albedinis della Phoenix canariensis. Notiziario sulle Malattie delle Piante 88/89:107-117.
Downer, A.J. and D.R. Hodel. 2007. Leaf removal from Washingtonia filifera does not prevent infection by Phaeochoropsis neowashingtoneae, but does predispose palms to early death from pink rot, Gliocladium vermoeseni. HortScience 42:978. (Abstr.).

Downer, A.J., D.R. Hodel, and M.J. Mochizuki. 2009. Pruning landscape palms. HortTechnology 19:695-699.

Downer, J. 2003a. Fusarium wilt or not? Landscape Notes 17(1):1-3.

Downer, J. 2003b. Palm disease notes: Pink rot. Landscape Notes 17(2):2-3.

Downer, J. 2006. Fusarium wilt pathogen of Phoenix canariensis is a soil survivor. Landscape Notes 19(3):1-2.

Elliott, M.L. 2004a. Diamond scale, p. 17. In: M.L. Elliott, T.K. Broschat, J.Y. Uchida, and G.W. Simone (eds.). Compendium of ornamental palm disease and disorders. APS Press, St. Paul, MN.

Elliott, M.L. 2004b. Ganoderma butt rot, p. 22-25. In: M.L. Elliott, T.K. Broschat, J.Y. Uchida, and G.W. Simone (eds.). Compendium of ornamental palm disease and disorders. APS Press, St. Paul, MN.

Elliot, M.L. 2006a. Fusarium wilt of canary island date palm. Univ. Florida Inst. Food Agr. Sci. Fact Sheet PP-215.

Elliott, M.L. 2006b. Theilaviopsis trunk rot of palm. Univ. Florida Inst. Food Agr. Sci. Fact Sheet PP-219.

Elliott, M.L. and T.K. Broschat. 2001. Observations and pathogenicity experiments on Ganoderma zonatum in Florida. Palms 45:62-72.

Feather, T.V. 1982. Occurrence etiology and control of wilt and dieback of Phoenix canariensis in California. Univ. California, Riverside, PhD. diss.

Feather, T.V., H.D. Ohr, and D.E. Munnecke. 1979. Wilt and dieback of canary island palm in California. Calif. Agr. 33: 19-20.

Feather, T.V., H.D. Ohr, D. Munnecke, and J.B. Carpenter. 1989. The occurrence of Fusarium oxysporum on Phoenix canariensis a potential danger to date production in California. Plant Dis. 73:78-80.

Garofalo, J.F. and R.T. McMillan. 2004. Thielaviopsis diseases of palms. Proc. Florida State Hort. Soc. 117:324-325.

Gunn, L.V. and B.A. Summerell. 1999. Fusarium wilt of canary island date palms. Proc. 52nd N.Z. Plant Protection Conf. p. 29-31.

Harrison, N.A. and P. Jones. 2004. Lethal yellowing, p. 39-41. In: Elliott M.L., Broschat T.K., Uchida, J.Y., Simone 
G.W. (eds.). Compendium of ornamental palm disease and disorders. APS Press, St. Paul, MN.

Harrison, N.A., W. Myrie, P. Jones, M.L. Carpio, M. Castillo, M.M. Doyle, and C. Oropeza. 2002. 16S rRNA interoperon sequence heterogeneity distinguishes strain populations of palm lethal yellowing phytoplasma in the Caribbean region. Ann. Appl. Biol. 141:183-193.

Hodel, D.R. 1985. Gliocladium and fusarium diseases of palms. Principes 29:85-88.

Hodel, D.R. 1999. Pruning palms. Principes 43:99-100.

Hodel, D.R. 2009. Palms in the landscape: Diseases II. Western Arborist $35: 20-27$.

Humphrey, W.A. and R. Keim. 1984. Control of Gliocladium disease of Chamaedorea palms. Flower and nursery report. Univ. California Coop. Ext. Fall 1983 and Spring 1984:5.

Keim, R., L.J. Klure, and G.A. Zentmeyer. 1979. Collar rot of Washingtonia palms in containers. Plant Dis. Rptr. 63:718-720.

Mercier, S. and J. Louvet. 1973. Recherches sur les furarioses. X. Une fusariose vasculaire (Fusarium oxysporum) du palmier des Canaries (Phoenix canariensis). Ann. Phytopathol. 5:203-211.

Plyler, T.R., G.W. Simone, D. Fernandez, and H.C. Kistler. 1999. Rapid detection of the Fusarium oxysporum lineage containing the canary island date palm wilt pathogen. Phytopathology 89:407-413.

Schroers, H.J., N.M. Geldenhuis, M.J. Wingfield, M.H. Schoeman, Y.F. Yen, W.C. Shen, and B.D. Wingfield. 2005. Classification of the guava wilt fungus Myxosporium psidii, the palm pathogen Gliocladium vermoeseni and the persimmon wilt fungus Acremonium diospyri in Nalanthamala. Mycologia 97:375-395.

Simone, G.W. 2004a. Canary island date palm wilt, p. 17-19. In: M.L. Elliott, T.K. Broschat, J.Y. Uchida, and G.W. Simone (eds.). Compendium of ornamental palm disease and disorders. APS Press, St. Paul, MN.

Simone, G.W. 2004b. Thielaviopsis diseases (black scorch, stem bleeding, dry basal rot, trunk rot, heart rot), p. 37-38. In: M.L. Elliott, T.K. Broschat, J.Y. Uchida, and G.W. Simone (eds.). Compendium of ornamental palm disease and disorders. APS Press, St. Paul, MN.
Simone, G.W. and G. Cashion. 2002. Fusarium wilt of canary island date palms in Florida. Univ. Florida Plant Pathol. Fact Sheet PP-44.

Summerell, B.A., D.I. Smith, L.V. Gunn, I.W. Smith, and I.G. Pascoe. 2006. Fusarium wilt of Phoenix canariensis in Victoria. Australas. Plant Pathol. 35:289-290.

Uchida, J.Y. 2004a. Gliocladium blight (pink rot), p. 25-26. In: M.L. Elliott, T.K. Broschat, J.Y. Uchida, and G.W. Simone (eds.). Compendium of ornamental palm disease and disorders. APS Press, St. Paul, MN.

Uchida, J.Y. 2004b. Phytophthora diseases, p. 29-32. In: M.L. Elliott, T.K. Broschat, J.Y. Uchida, and G.W. Simone (eds.). Compendium of ornamental palm disease and disorders. APS Press, St. Paul, $\mathrm{MN}$.

Uchida, J.Y., J.J. Ooka, N.M. Nagata, and C.Y. Kadooka. 1992b. A new Phytophthora fruit and heart rot of coconut. Univ. Hawaii, Hawaii Inst. Trop. Agr. Human Resources Res. Ext. Ser. 138.

Uchida, J.Y., M. Aragaki, J.J. Ooka, and N.M. Nagata. 1992a. Phytophthora fruit and heart rot of coconut in Hawaii. Plant Dis. 76:925-927. 